\title{
Calibration of Relative Humidity with Artificial Mass Method in Biogas Plant
}

\author{
Qoriatul Fitriyah" Muhammad Prihadi Eko Wahyudi* Markus Grömping*** \\ *Politeknik Negeri Batam, Batam, Indonesia \\ Electrical Engineering Study Program \\ Jl. Ahmad Yani, Batam Center, Batam 29461, Indonesia \\ ${ }^{* *}$ Fachhochschule Aachen, Aachen, Germany \\ Department of Urban Water Management and Waste Technology \\ Email: fitriyah@polibatam.ac.id, prihadieko@ polibatam.ac.id, groemping@ fh-aachen.de
}

\begin{abstract}
Biogas plant needs to be given specific amount of relative humidity setting in order to make it work optimally. It is one major factors of gas waste adsorption through final process of activated carbon in biogas plant, especially for hydrogen sulfide. Hydrogen sulfide is a side gas appeared in biogas plant which has to be removed by various processes, including the presence of activated carbon filter that usually appeared on last stage of biomass filtration process which is poisonous and corrosive to the metal parts. Today, air humidity gauges have been found quite a lot on the market. However, how accurate the device is, needs to be further proven in the laboratory, especially when the gauges have to face corrosive gases such as this $\mathrm{H}_{2} \mathrm{~S}$. Therefore, calibration for cheap and efficient relative humidity measurement is very necessary. The method will use comparison between $R H$ reading and $R H$ calculation based on parameters of plant settings in the form of gas composition mixture, flow duration, pressure, volumetric flow rate, and temperature. This paper will discuss how to calculate and measure calibration for relative humidity that is practical, simple and does not cost much so that it is expected to be used for low-funding research in biogas plant.
\end{abstract}

Keywords: Relative Humidity, Calibration, Artificial Mass Method, Biogas Plant, Renewable Energy

\section{INTRODUCTION}

Biogas is a burnable gas earned by fermentation of organic matters under anaerobic condition. The main constituent of biogas is methane gas, carbon dioxide and small amount of other gases such as hydrogen sulfide, carbon monoxide and ammonia [1-5]. Biogas has high calorific value and it has been considered as good example of energy resource. A burnable methane from biogas plant turned into carbon dioxide, able to reduce greenhouse effect. If this heat can be utilized, it could save up significant amount of energy. Thus, goal of carbon reduction and energy saving will be reached synchronously [1, 6]. Therefore is considered as carbon neutral due to the fact that carbon in biomass is shifted through gas phase. It can be produced from many kind of organic substrates such as crop field, sludge water or even animal waste.[7-13]
The formation of methane 1) from biomass follows in general the equation:

$$
\begin{gathered}
\mathrm{C}_{c} \mathrm{H}_{h} \mathrm{O}_{o} \mathrm{~N}_{n} \mathrm{~S}_{s}+y \mathrm{H}_{2} \mathrm{O} \rightarrow x \mathrm{CH}_{4}+n \mathrm{NH}_{3}+s \mathrm{H}_{2} \mathrm{~S}+(c- \\
x) \mathrm{CO}_{2} \\
x=1 / 8 .(4 c+h-20-3 n-2 s) \\
y=1 / 4 .(4 c-h-20+3 n+3 s)[14] \\
\text { Products are: }
\end{gathered}
$$

$$
\begin{gathered}
\text { Carbohydrate: } \quad \mathrm{C}_{6} \mathrm{H}_{12} \mathrm{O}_{6} \rightarrow 3 \mathrm{CO}_{2}+3 \mathrm{CH}_{4} \\
\text { Fats: } \quad \mathrm{C}_{12} \mathrm{H}_{24} \mathrm{O}_{6}+3 \mathrm{H}_{2} \mathrm{O} \rightarrow 4.5 \mathrm{CO}_{2}+7.5 \mathrm{CH}_{4} \\
\text { Proteins: } \mathrm{C}_{13} \mathrm{H}_{25} \mathrm{O}_{7} \mathrm{~N}_{3} \mathrm{~S}+6 \mathrm{H}_{2} \mathrm{O} \rightarrow 6.5 \mathrm{CO}_{2}+6.5 \\
\mathrm{CH}_{4}+\mathrm{NH}_{3}+\mathrm{H}_{2} \mathrm{~S}[14]
\end{gathered}
$$

So that the general biogas composition is:

$$
\mathrm{CH}_{4}: \mathrm{CO}_{2}=71 \%: 29 \%[14]
$$


From the preliminary research of [15], data below are given:

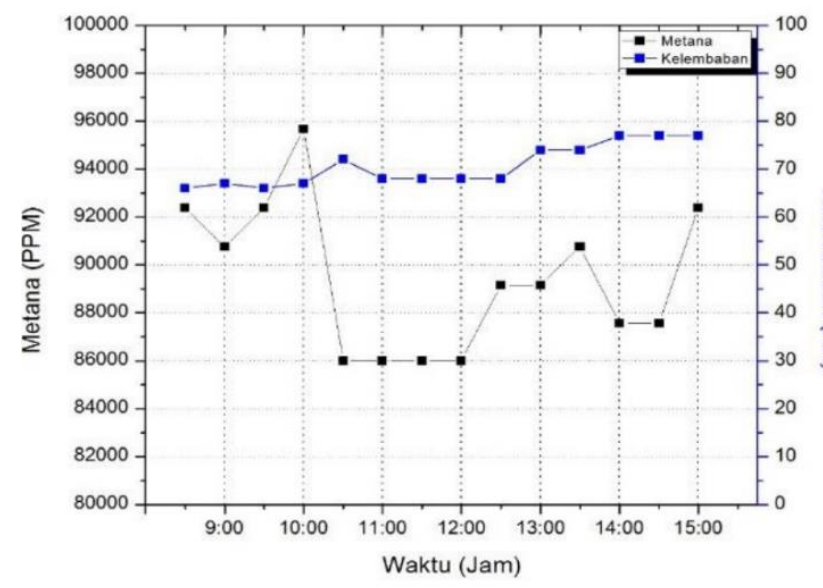

Figure 1. Correlation between relative humidity and Biogas Production [15]

Parameter of temperature, relative humidity and pressure could affect biogas production. From testing plant, it is known that highest production of methane gas happened at 10:00 AM with 95,672 ppm gases with temperature of $34^{\circ} \mathrm{C}$ and $67 \% \mathrm{RH}$, while for hydrogen happened at 14:00 AM with $4.738 \mathrm{ppm}$, temperature of $34^{\circ} \mathrm{C}$ and $74 \% \mathrm{RH}$, and $\mathrm{CO}_{2}$ get its peak at 11:00 AM with $16.89 \mathrm{ppm}$ and $68 \%$ RH[15].

Humidity refers to the amount of water vapor in the air. The higher the air temperature, the more water vapor that air can hold. (http://www.just4growers.com). Absolute humidity is the measure of water vapor (moisture) in the air, regardless of temperature. It is expressed as grams of moisture per cubic meter of air $\left(\mathrm{g} / \mathrm{m}^{3}\right)$. Relative humidity also measures water vapor but relative to the temperature of the air. It is expressed as the amount of water vapor in the air as percentage of the total amount that could be held at its current temperature. In another way, relative humidity is the ration of current absolute humidity to the highest possible absolute humidity (which depends on the current air temperature).

$100 \%$ humidity means that the air is totally saturated with water vapor and cannot hold it anymore. Just as increasing the temperature decreases relative humidity, decreasing the temperature increases the relative humidity. If you keep on decreasing the temperature without changing the air's moisture content significantly, eventually you'll reach 100 percent relative humidity, and then water vapor will start to condense to form dew. The temperature when this happens is called the dew point, and this phenomenon is what causes dew to form on the grass on chilly mornings. (http://science.opposingviews.com/happens-relativehumidity-airtemperature-rises-22563.html)

Meanwhile, it is stated that hydrogen sulfide as a waste product of biogas plant has to be removed from the system afterwards. $\mathrm{H}_{2} \mathrm{~S}$ compete with water vapor decreases the adsorption capacity of the filter.[7]

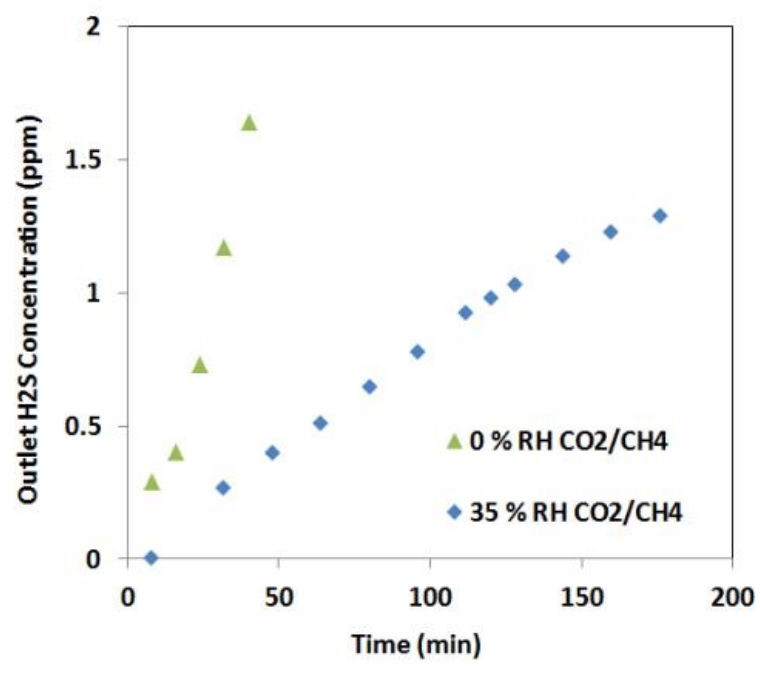

Figure 2. Effect of relative humidity on outlet $\mathrm{H}_{2} \mathrm{~S}$ concentration in $\mathrm{CO}_{2} / \mathrm{CH}_{4}$ [16]

By $0 \%$ of $\mathrm{RH}$, the outlet concentration of $\mathrm{H}_{2} \mathrm{~S}$ tends to be higher compared to $35 \%$ of RH [16], so that the specific selection of relative humidity in the biogas plant is absolutely essential. Relative humidity needs to be carefully controlled for input and output. In addition, it is necessary to periodically test the performance of humidity gauges, because one of the biogas by-products is hydrogen sulfide which is corrosive and tends to damage metal components in a short time.

\section{METODOLOGY}

This methodology was given out by laboratory experiments in which a mixture of gas from an artificial biogas plant was in the form of nitrogen instead of methane gas. Other gases were ignored for simplicity because their molar masses were quite small compared to nitrogen. Controlling the humidity setting is done through the use of a water bath, by comparing the measured mass loss of the wash bottle over a certain period with the theoretical calculations. As much as $50 \%$ volume of nitrogen was flowed in a PTFE pipe tube with a gas flow of 22 liters per minute, for a certain time. The pipe tube was then connected with a glass containing 
heated water. This gas would carry a certain amount of moisture from the glass tube, then this wet nitrogen would be mixed with the rest of $50 \%$ dry nitrogen gas and then sent to the sensor to be read how much is the relative humidity.

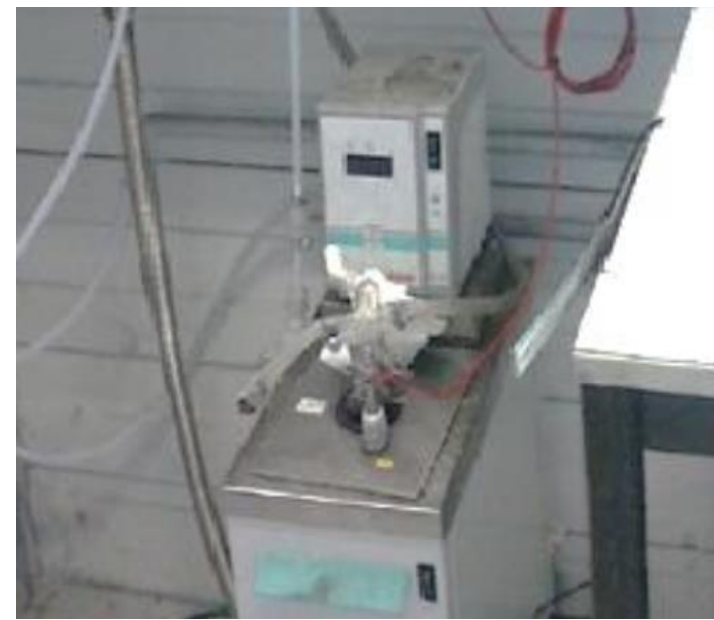

Figure 3. Water bath reactor in this experiment

Table 1. Experimental Apparatus Needed for the Research

\begin{tabular}{|l|r|}
\hline Remark & Amount \\
\hline Relative Humidity Sensor & 1 \\
Glass Bottle & 1 \\
Nitrogen Gas Tank & 1 \\
Water Heater & 1 \\
\hline
\end{tabular}

To examine the accuracy of the research, the reading from the sensor would be compared with the measurement results, where the remaining water in the glass tube would be weighed and then calculated and compared with the sensor readings to measure the percentage error. This experiment was carried out continuously until the error gap between reading and measurement reached $4 \%$ as the maximum proposed of deviation limit.
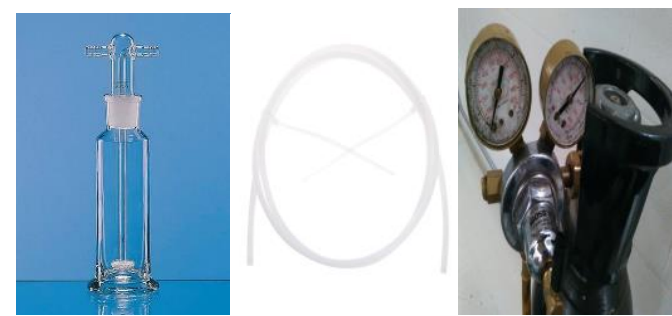

Figure 4. Apparatus Needed on the Experiment [17]
Using flowchart, the step processes are as follows:

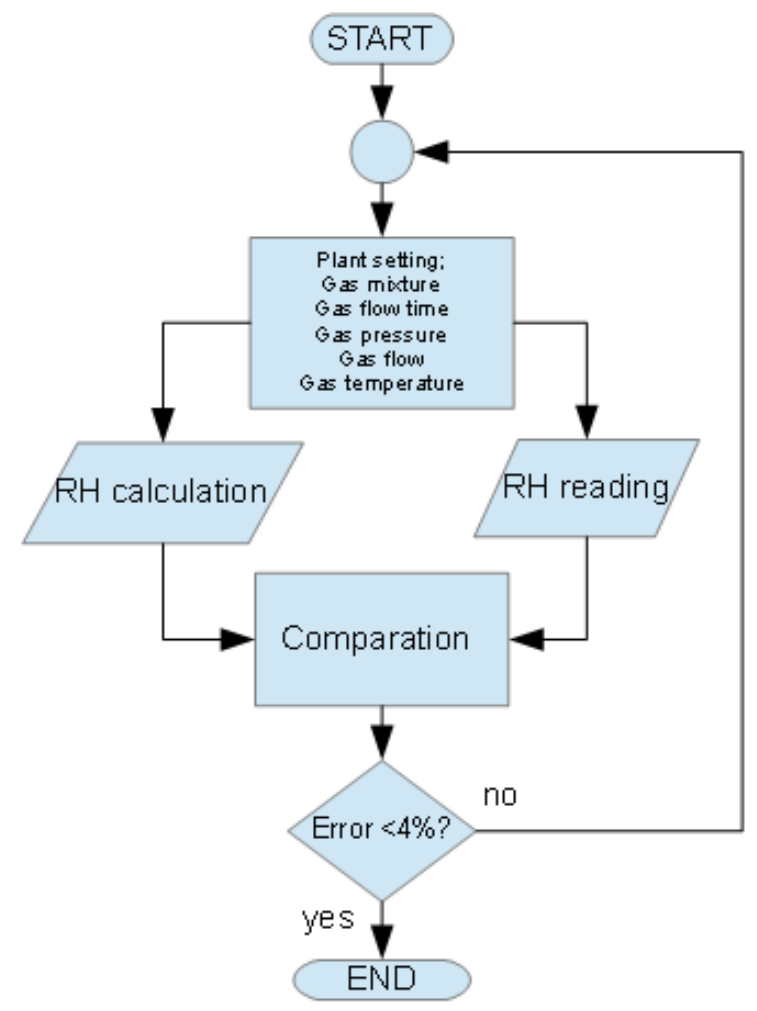

Figure 5. Flowchart of the process

Error is needed below $4 \%$ to keep the device proven and reliable.

\section{RESULTS AND ANALYSIS}

As for the correlation between temperature and pressure of water vapor, it can be seen from graph below:

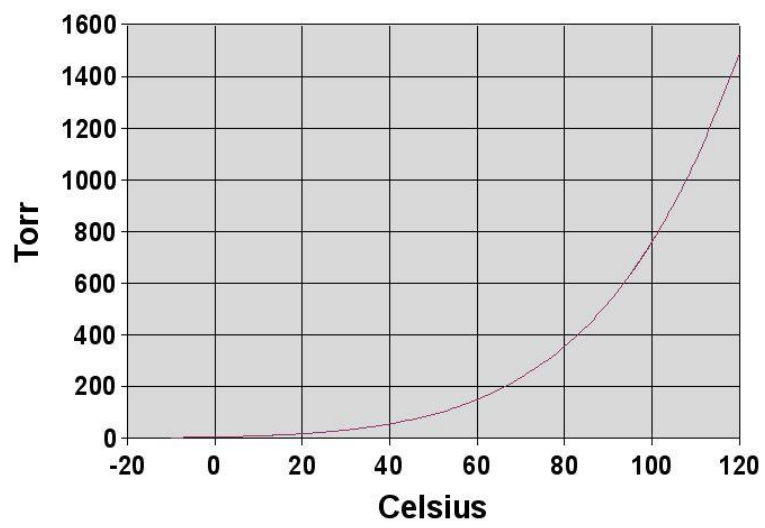

Figure 6. Water Vapor Pressure Graph[18]

As the water temperature increased, the water vapor pressure is also rising. The increment happened in logarithmic not a linear function. 
From this graph, then measurement is started according to functions:

$m N_{2}=\frac{P_{N_{2}} \times \dot{V}_{N_{2}} \times t \times M r N_{2}}{R \times T}$

With:

$\mathrm{mN}_{2} \quad$ mass of Nitrogen (g)

$P_{N_{2}} \quad$ total pressure of Nitrogen (atm)

$\dot{V}_{N_{2}} \quad$ volume flow rate of Nitrogen (1/min)

$t$ time of Nitrogen's flow duration (min)

$\mathrm{Mr} \mathrm{N}_{2}$ molar mass of Nitrogen $(\mathrm{g} / \mathrm{mol})$

$R \quad$ universal gas constant $(\mathrm{L}$ atm $/ \mathrm{mol} \mathrm{K})$

$T$ temperature of Nitrogen/room temperature

(K)

Whereas:

$\frac{m N_{2}}{m \mathrm{H}_{2} \mathrm{O}}=\frac{P_{\mathrm{N}_{2}} \times \mathrm{MrN}_{2}}{P_{\mathrm{H}_{2} \mathrm{O}} \times \mathrm{Mr} \mathrm{H} \mathrm{H}_{2} \mathrm{O}}$

With:

$\mathrm{mN}_{2} \quad$ mass of Nitrogen (g)

$P_{N_{2}} \quad$ total pressure of Nitrogen (atm)

$\mathrm{Mr} \mathrm{N}_{2}$ molar mass of Nitrogen $(\mathrm{g} / \mathrm{mol})$

$P_{\mathrm{H}_{2} \mathrm{O}} \quad$ total pressure of Oxygen (atm)

$\mathrm{Mr} \mathrm{H}_{2} \mathrm{O}$ molar mass of Oxygen $(\mathrm{g} / \mathrm{mol})$

By using those equation, mass of water vapor can be found theoretically, and therefore, compared with data obtained through measurement. These two data are stacked up until the error margin reach equal or less than $4 \%$.

The following records are data from calculations and laboratory measurements:

Table 2. Calculation Data for Respective RH

\begin{tabular}{|c|c|c|c|c|c|c|}
\hline $\begin{array}{l}\text { RH } \\
\text { Setting } \\
(\%)\end{array}$ & $\begin{array}{l}\mathrm{PH}_{2} \mathrm{O} \\
\text { (bar) }\end{array}$ & $\begin{array}{l}\mathrm{PN}_{2} \\
\text { (bar) }\end{array}$ & $\begin{array}{l}\dot{\mathrm{V}} \mathrm{N}_{2} \\
(1 / \mathrm{min})\end{array}$ & $\begin{array}{l}\text { time } \\
\text { (min) }\end{array}$ & $\begin{array}{l}\text { Temp } \\
\left({ }^{\circ} \mathrm{K}\right)\end{array}$ & $\begin{array}{l}\text { total } \\
\text { mass } \\
\text { theoretic } \\
\text { ally } \\
\text { gone as } \\
\mathrm{RH}(\mathrm{g})\end{array}$ \\
\hline 48 & 0.01173 & 1.2 & 22 & 265 & 293.7 & 33.19 \\
\hline 47 & 0.01611 & 1.2 & 22 & 376 & 293.5 & 47.10 \\
\hline 46 & 0.01611 & 1.2 & 22 & 236 & 293.9 & 44.04 \\
\hline 48 & 0.01611 & 1.2 & 22 & 408 & 293.5 & 51.11 \\
\hline 48 & 0.01611 & 1.2 & 22 & 410 & 293.5 & 51.36 \\
\hline
\end{tabular}

The biogas volumetric flow rate which is represented here by nitrogen gas, flow through PTFE tube with volumetric flow rate 22 liter/minute for a certain duration of time for each of relative humidity setting. The temperatures are kept constant and its mass $\left(\mathrm{H}_{2} \mathrm{O}\right)$ which turn into relative humidity is calculated. The mass data are the compared to the measurement data in the laboratory which is shown in the table below:

Table 3. Laboratory Data for Respective $\mathrm{RH}$

\begin{tabular}{|c|c|c|c|c|c|}
\hline \multirow[b]{2}{*}{$\begin{array}{l}\text { RH } \\
\text { Setting } \\
\text { (\%) }\end{array}$} & \multicolumn{3}{|c|}{$\mathrm{mH}_{2} \mathrm{O}$ in bottle } & \multirow[b]{2}{*}{$\begin{array}{l}\text { Mass } \\
\text { Error } \\
(\%)\end{array}$} & \multirow[b]{2}{*}{$\begin{array}{l}\text { RH in } \\
\text { Reality } \\
\text { (\%) }\end{array}$} \\
\hline & $\begin{array}{l}\text { before } \\
\text { experi- } \\
\text { ment } \\
\text { (g) }\end{array}$ & $\begin{array}{l}\text { after } \\
\text { experi- } \\
\text { ment } \\
\text { (g) }\end{array}$ & $\begin{array}{l}\text { after experi- } \\
\text { ment } \\
\text { theoretically } \\
\text { (g) }\end{array}$ & & \\
\hline 48 & 102.14 & 64.230 & 68.952 & 6.14 & 50.94 \\
\hline 47 & 60 & 9.086 & 12.901 & 6.36 & 49.99 \\
\hline 46 & 115.6 & 66.94 & 71.562 & 4.00 & 47.84 \\
\hline 48 & 115.6 & 59.81 & 64.493 & 4.05 & 49.94 \\
\hline 48 & 115.6 & 59.81 & 64.242 & 3.83 & 49.84 \\
\hline
\end{tabular}

The water inside bottle is measured before and after experiment. As an example, for first data for $48 \%$ relative humidity, the mass of water was 102.14 gram before experiment and after some part of biogas flowing through the bottle for 265 minutes with temperature of $293.7 \mathrm{~K}$, the remaining water mass inside is $64.230 \mathrm{~g}$ while according to calculation, the water should be weighed at $68.952 \mathrm{~g}$ which means that the mass error is $6.14 \%$. Consequently, its relative humidity supposed to be $50.94 \%$ rather than $48 \%$ via sensor reading.

\section{CONCLUSION}

In order to reduce the mass error less than $4 \%$, several steps are need to be done such as keeping the temperature's stability or doing adjustment on surface area, homogeneously, with expectation of increasing reaction rate between water and biogas. 


\section{REFERENCES}

[1] Cheng-Chang Lien, C.-H.T., Piglets Comfort with Hot Water by Biogas Combustion under Controllable Ventilation. AITI, 2018. 3.

[2] P. V. Rao, S.B.S., R. Dey, and S. Mutnuri, Biogas generation potential by anaerobic digestion for sustainable energy development in india. Renewable and Sustainable Energy Reviews, September 2010. vol. 14, no. 7: p. pp. 2086-2094.

[3] Fleming, M.V.H.a.R., Electricity and heat production using biogas from the anaerobic digestion of livestock manureliterature review, R.C. University of Guelph, Editor. 2005.

[4] J. B. Holm-Nielsen, T.A.S., and P. Oleskowicz-Popiel, The future of anaerobic digestion and biogas utilization. Bioresource Technology, November 2009. vol. 100, no. 22: p. pp. 5478-5484.

[5] R. C. Saxena, D.K.A., and H. B. Goyal, "Biomass-based energy fuel through biochemical routes: a review". Renewable and Sustainable Energy Reviews, January 2009. vol. 13, no. 1: p. pp. 167-178.

[6] C. C. Su, C.M.H., M. T. Koh, and S. Y. Sheen, Swine waste treatment in taiwan, T.L.R.I. Department of Livestock Management, Editor. 1994.

[7] Davide Papurello, M.S., and Sonia Fiorilli, Physical Activation of Waste-Derived Materials for Biogas Cleaning. Energies, September 2018.

[8] Torrijos, M., State of Development of Biogas Production in Europe. Procedia Environ.Sci., 2016. 35: p. 881-889.

[9] Papurello, D.S., C.; Schuhfried, E.; Cappellin, L.; Gasperi, F.; Silvestri, S.; Santarelli, M.; Biasioli, F., Monitoring of volatile compound emissions during dry anaerobic digestion of the Organic Fraction of Municipal Solid Waste by
Proton Transfer Reaction Time-of-Flight Mass Spectrometry. Bioresour. Technol, 2012. 126.

[10]Papurello, D.L., A, SOFC single cells fed by biogas: Experimental tests with trace contaminants. Waste Manag., 2017.

[11]Papurello, D.S., S.; Tomasi, L.; Belcari, I.; Biasioli, F.; Santarelli, M, Biowaste for SOFCs. Energy Procedia, 2016. 101: p. 424-431.

[12]Rasi, S.V., A.; Rintala, J. , Trace compounds of biogas from different biogas production plants. Energy 2007. 32: p. 1375-1380.

[13]Rasi, S.L., J.; Rintala, J. , Trace compounds affecting biogas energy utilisation-A review. Energy Convers. Manag., 2011. 52: p. 3369-3375.

[14]Dieter Deublein, A.S., Biogas from Waste and Renewable Resources: An Introduction. 2008, Wiley-VCH.

[15]Rocky Alfanz, A.N., Joddy Arya Laksmono, PERANCANGAN DAN IMPLEMENTASI SISTEM MONITORING PRODUKSI BIOGAS PADA BIODIGESTER. Jurnal Nasional Teknik Elektro, Maret 2016. 5 No.1.

[16]Isik-Gulsac, I., INVESTIGATION OF IMPREGNATED ACTIVATED CARBON PROPERTIES USED IN HYDROGEN SULFIDE FINE REMOVAL. Brazilian Journal of Chemical Engineering, 2015. 33: p. pp. $1021-1030$.

[17]McCreadie, G. Nitrogen Tank Safety. Feb 17, 2018; Available from: https://www.hvacknowitall.com/blogs/tips/ 176370-nitrogen-tank-and-gaugeprecautions\#.W6h4_mgzbIU.

[18]Trottier, Y., 2006. 